\title{
Metaphorical Signification in Henry James's The Wings of the Dove: A Deconstructive Reading
}

\author{
Ali Taghizadeh \\ Department of English, Razi University, Kermanshah, Iran
}

\begin{abstract}
The later style of Henry James is an antidote to the provincialism of the Victorian English fiction. To supply his antidote, James attempted to provide his readers with a form of fiction which is integrally metaphorical. In The Wings of the Dove such a metaphorical signification is achieved, among other things, through water symbolism, a character who is different from what she is, structural biaxiality, ubiquitous appearances, and a policy of concealment. Such strategies render this story a field of deconstructive analysis. A main outcome of reading it deconstructively is a perpetual deferment of signification through the cancellation of its discourse which grounds the production of a number of counter-discourses.
\end{abstract}

Index Terms - deconstructive analysis, The Wings of the Dove, water symbolism, structural biaxiality, ubiquitous appearances, concealment policy

\section{INTRODUCTION: VITALIZATION OF STRUCTURE}

What the German philosopher Ludwig Klages called "logocentrism" was used to refer to a tradition from the formation of the Western science and philosophy that assumed the possibility of knowledge only in a system or structure of which the word or logos is epistemologically the superior element because it would give us direct access to the meaning or reality. Ferdinand de Saussure, the Swiss philosopher and semiologist, provided the ground for the $19^{\text {th }}$ century philology to be evolved into the $20^{\text {th }}$-century linguistics. He theorized that a word is not a symbol which can be equal to the concrete thing which it represents, but is a sign of which the signifier (the spoken sound or the written mark) only entails the signified, while the latter is not the thing itself but is the concept of the thing, and is therefore available only in the mind. He also asserted that the connection between the sign and the signified is not given (natural) but is arbitrary and conventional, and is the result of the relations and differences of the signifiers.

However, as it came out, it became clear that Saussure was still following the Klagian logo-centric line of thought, because he had limited the application of the play of relations to the signifiers, and had denied it of the signifieds. But taking a step forward to the findings of the Swiss linguist, Derrida brings the signified into the cycle of the free play also. Charles E. Bressler says

Derrida agrees with Saussure that we can know the meaning of signifiers through and because of their relationships and their differences among themselves. Unlike Saussure, Derrida also applies this reasoning to the signified. Like the signifier, the signified (or concept) can also be known only through its relationships and its differences from other signifieds" (p. 75).

What Derrida calls "metaphysics of presence" is a tendency from the time of Plato in the West to accept immediate access to meaning in the word, in the logos. In a paper which he delivered in 1966 he said "the concept of structure and even the word 'structure' ... has been neutralized or reduced, and this by a process of giving it a center." Derrida argued that the function of this center in the Western thought has been "to make sure that the organizing principle of the structure would limit what we might call the free play of the structure" $(2001$, p. 1$)$.

But in the same paper he successfully sought to refute this doctrine in order to demolish the 'center' which he believed had repealed the "structurality of structure" in the Western intellectual tradition. By doing this, he intended to vitalize the possibility of the free play of relations in the structures of meaning like language, literature, religion, fashion, sport, etc. In this way, he asserted that the word or the logos contains the seed of no spontaneous experience but it is the relations and differences of the sign in such structures which ground the production of meaning. Therefore, Derrida rejected the meaning as fixedly stored in the word. Instead, he proposed it as an in-between entity which is the product of the free play of the sign and which is therefore not only relative but relational also.

Later thinkers admit that the researches of Derrida have paved the way for the "event" which he had predicted to take place in humanities. Christopher Norris approves of deconstruction as a turning upside down of the Western "metaphysics of presence." Denying that logo-centrism includes the seed of any fresh and genuine thought, meaning, or experience, Norris claims that deconstruction is a necessary "knock-down argument against" (2002, p. 140) logo-centric discourses. Also, the argument of Peter J. Leithart in "Derrida and Metaphor" confirms the assertion of Norris: 
"deconstruction carries on the critique of established (...) modes of perception or conceptualization which has characterized philosophy in the tradition from Aristotle to Descartes, Kant, and Husserl." 1

In Derridean deconstruction, experience is an in-between spontaneous entity which emerges and evolves in a process of interpretive interaction. If this is right, the later style of Henry James can be read deconstructively fruitfully, because attempting to escape the Victorian literary vulgarism (provincialism) of his time, he established a new mode of fiction which highlights the functioning of language and in which therefore the free play of the signifier often cancels the narrative energy to change it into a counter-narrative. This later James believes in experience as an intermediary and relational entity which is the result of the critical thinking of the reader in the space of language.

James's fiction is a space for practicing free and spontaneous thinking for the production of new meanings through a destruction of logo-centric frames of intelligibility. In his later style we can witness the refutation of logo-centric norms of thought and the emergence of phenomenological realities which are the outcome of the functioning of language in the consciousness. In this way, the later James and Derrida admit the formation of meaning through the practice of writing and reading, through analytical criticism of literature where man's free conscience can navigate through the stormy waves of life to achieve recognition.

On the basis of these hypotheses, the present paper will argue that recognition in The Wings of the Dove is mainly metaphorical. The spontaneity of thought, the metamorphosis of Milly Theale, the omnipresence of appearances, structural biaxiality, and the policy of concealment are among the techniques James uses for achieving a certain novelistic form that wants to provide a space of metaphoric recognition. In the light of deconstructive theory, it will be argued that these priorities render the novel a fertile field for the production of such metaphorical meanings. To achieve this goal, the writer will closely read the novel to show how its discourse punctures the established norms of narrativity for the emergence of new experiences via the cancellation of the logic of the binary oppositions for example.

\section{DISCUSSION}

\section{A. Water as Symbol}

Water as symbol is a certain dimension of a deconstructive analysis of The Wings of the Dove, because it makes a productive ground of recognition in it. For an example, in Book 8 chapter 3, James compares the people in the Lancaster Gate to the fish in a pool.

There was a deeper depth of it, doubtless, for some than for others; what he (Milly's doctor), at any rate, in particular knew of it was that he seemed to stand in it up to his neck. He moved about in it, and it made no plash; he floated, he noiselessly swam in it; and they were all together, for that matter, like fishes in a crystal pool (2004, pp. 527-528).

For James, a narrative is, metaphorically speaking, a flowing river where every character swims to reconstruct and update himself by getting new experiences through standing in meaningful relations with other characters. Unlike the logos, which is the meaning consolidated in the pool of the single word, experience, which is flowing and spontaneous, is performed through dynamism, through interaction in the vast realm of the sea. Therefore, like when one washes himself in the water, a character can approve the becoming of his consciousness only by swimming in the river of experiences. Or like a whale in the ocean, which dies out of water, out of the waters of spontaneity experience gets stale; for it is only in the flow of life that it can be developed. Therefore, it is on the waves of narrative as a verbal construction that reciprocal connections are restored among the members of a society and the collective experience is promoted.

However, for F. O. Mmatthiessen,

What James seems to want most to suggest through such an image is the denseness of experience, the way in which the Jamesian individual feels that he is held into close contact with his special group, the slowly circulating motion of their existence all open to an observing eye, and, particularly as Densher develops this image, with an oppressive sense of the complexities in which he is immersed, of being plunged into an element "rather more strangely than agreeably warm" (p. 63).

For Matthiessen this symbol belongs to a variety of images in James that implies the people of a same social group whose collective experience in the flux of life is the meaning of their being and humanity. It signifies perhaps not only the extra delicacy of our consciousness, but also the real fluidity of experience. It shows experience as fully complex and dynamic, which is the subject to perpetual examination and refutation.

\section{B. Milly Theale as Metaphor}

In the third chapter of Book 7, where Milly Theale resides in Palazzo Leporelli in Italy till she dies, she is presented with a "renewed flare of fancy" (James, 2004, p. 452). The discourse lets the reader sway between reality and phantom while Milly's identity remains fully enigmatic. But why does Milly, when she is in the event of her pending death, take refuge in the solitude of such a relic of the past? When she knows that she will die soon, she goes to the stillness of the palace perhaps to listen to the up-to-now unheard voices scattered on the long plateau of the past history of mankind. By doing this, she wants to depart to the frozen plains of death, to the unlimited eternity. She wants to withdraw into a past

\footnotetext{
Leithart, Peter J. /LEITHART.COM/ "Derrida and Metaphor." posted on Friday, December 23, 2005, at 5:30 PM. http://www.leithart.com/2005/12/23/derrida-and-metaphor/.
} 
culture that is no longer alive, and thereby she wants to enter the soul of creation and become a part of it. By making her dye in this certain way, it seems that the author wants to change her into a metaphor, that is, to metamorphose her reality into an illusion.

For example, when Lord Mark visits her in the palace, she is in her "excluded disinherited state" which is different from that of the 'naturalistic' Kate. Under the charm of this position, she undergoes a radical change, and is translated into something like an image, like an aspiration, to whom a truth is revealing. Later on, she even goes through more advanced stages of metaphoricality, because she sees a 'face' that speaks for her about "a possible but forbidden life" (ibid., p. 465).

Now, if we accept that a great novel like The Wings should avoid confusing the reader, why should James make his story into a real enigma by changing Milly into a metaphor? An immediate solution is that Milly as metaphor is, in the Jamesian "house of fiction," a real cornerstone, a determining narrative policy, because it takes elemental functions in more than one section of the story. Like in the Bronzino painting, which is “emblematic of Milly's ultimate beauty's emerging after her death" (Ward, 1967, pp. 189-190), James even uses 'face' and 'light' to complete the process of her metamorphosis, because her metamorphosis into a metaphor is not only a device of recognition, but also a space for enlightenment.

It is in the space of The Wings as metaphorical that one can believe in the talks of Nicola Bradbury when she compares The Wings with The Ambassadors. In her comparison, she points to the duality of The Ambassadors and the multiplicity of The Wings, she points to the un-reconciling contraries of the latter which challenge and supersede each other; and she points to the different approaches which should be tried and abandoned in reading The Wings. She also admits that hypothesis and extravagance characterize this work, and that resolution in it is not the product of reconciliation, but is the outcome of the rejection of excess. At the end, Bradbury affirms that "The process and effect of the novel are much less poised than in The Ambassadors" (1979, p. 73). In this way, one can argue that the formation of these features in this novel is considerably due to the metamorphosis of Milly, because it is the axis of a determining multi-dimensionality in this novel which makes it fruitfully ambiguous also. Milly as metaphor renders The Wings a story for which no straightforward reading is adequate. This is due to some of its additional features: in its consciousness centers it is quite varied, in the logic of its speech it is rather irregular, and in its overall structure it is unbalanced. For example, when Mark negotiates with Milly about marriage, the story can be rarely labeled as a talk in the form of an interior monolog or a real conversation conducted by some people.

In the representation of Milly as metaphor, a stylistic feature of The Wings is the annulment of all her paraphernalia which pertain to the material life. When Mark asks her if she is really not well, she realizes that her value for her wouldbe lover may be "precisely in the ravage of her disease" (James, 2004, p. 467). And after she draws inferences about Mark's incapability of pure love, she decides she will not marry him; because she thinks his love is mingled with pity and self-interest. In addition, when she admits she is ill and Mark offers to take care of her, she replies he is not good for her present situation. Also, when Mark claims that it is his suppressed life which has made him tormented, and that he will surely make his lovers happy, Milly decides she cannot marry him, because his remarks reveal that he thinks of marriage not as love but as bargain, while she does not think of marriage as bargain.

Another stylistic feature of this story is the application of techniques which mystify the reader. For example, when James compares his intended audience to the "fish rising to more delicate bait," it indicates that his mystification policies considerably work in the story. Thus, one can believe in D. W. Jefferson when he says "Nothing in Jamesian criticism is more remarkable than the widespread failure to appreciate Milly" (p. 202), because in the ground of its highlighted structural ambiguity, its discourse is often apt to mystify even the trained reader. A technique here is (intentional) stylistic deviations from the norms of the English literary language of the Victorian era. R. W. Short discusses the application of a number of such techniques in James's later style: the parenthetical phrase, the abnormal sentence order, the emphasis on relating expressions, the grammatically ambiguous sentence, and the stylization ${ }^{2}$. Whatever else the impact of these techniques may be, they also render this story a field of deconstructive analysis, which is also the meaning of a perpetual postponement or even cancellation of signification. Yet, canceling signification is, in its turn, not only a strategy for developing a professional readership, but also a possibility of multilateral discursivities.

\section{The Empire of the Appearance}

What makes James's fiction mainly a 'symptomatic' case of interpretation is perhaps its masterfully metaphorical representation which guarantees the formation of numerous shows, appearances. Milly is a meek American girl whom the narrative requires that she be deceived by another woman. Therefore, whatever she is, a dimension of her existence is that we should consider her not for her reality but mainly for her unreality, for what she is not, what the story shows of her. She is, as Jefferson says again, "among those on whom little or nothing is lost" (p. 205). In the first chapter of Book 8 , the story suggests that Densher wants to connect logos to experience, that is, to come further out from the realm of thought to the realm of life. But when he understands that Kate has close control over him, he doubts "whether he had really no will left" (James, 2004, p. 493). He realizes that he is being controlled by the strategy of the false, the strategy of the appearance; and that there is no far distance between life and lie.

\footnotetext{
2. "The Sentence Structure of Henry James," American Literature, Vol. 18, March 1946 - January 1947, pp. 71-88.
} 
In the fiction of James, representation turns on the hinge not of the abstract but of the concrete. This is to mean that James does not set forth the typical idea of his tale through abstract theorization, but he treats it through figures, images, and appearances which are part and parcel of the structure of it. J. A. Ward argues that such assimilations do not emerge for nothing, but are the result of the omnipresent relations which stop nowhere, and a certain authorial logic the application of which guarantees the composition of an "achieved novel." ${ }^{3}$ Therefore, however it is often assumed that Kate is of no appearances, Densher has no control over her. For him, this situation is like a test the outcome of which is anger and shame. His abstract, passive, and impersonal language signifies that he is the victim of an empire of appearances, of the suppressed shows and feelings.

The strategy of the false works in the third chapter of Book 8 also, which mystifies both Densher and the reader. The story simultaneously reveals and hides the question of the health of the American innocent. Now, under the influence of a two-way approach to mystification, the plot loses a big share of its merit, and the reader and character are left to determine the right path through the context via the implementation of a more "useful function" of consideration. If Kate is, for Milly, a queen of the appearance, Densher is also, for the former, a king of the false, because although he shows that he is "acting for Kate, and not, by the deviation of an inch, for her friend" (James, 2004, p. 519), in the course of time he changes his mind, he takes his love back from the English beauty and gives it to (the memory of) the American heiress.

As the time passes, the relations between the English boy and girl grow shakier; and a part of the two remaining books of the novel shows how each of them doubts if the other one really loves him/her, and how this prevents their trust and understanding; so that their marriage is no resolution. To achieve her ideals, the narrative represents the English girl in a way that the logic of her head is superior to that of her heart. This makes her a more enigmatic case for her lover, for it makes her able to accomplish a "heroic ring." Although the narrative seems ironical here, Kate's lover feels more incapacitated, because in relation with her, he always feels under-recognition, feels something is in her that he needs to decipher, while he will struggle more severely for independent knowledge and voice. But Kate is also afraid he may lose his confidence in her.

Thus, for her to retain his confidence, the story delivers her discourse in a more self-sufficient style. Although his doubt makes him curious for independent knowledge, it also makes him submissive to her discourse. The virtuality of this situation, however may at first suggest that it is rather improbable, but nevertheless also implies its possibility. Densher's thoughtful questions, Kate's decisive retorts that "touched the truth" (James, 2004, p. 544), and Milly's prolonged silence which suggests her solitary considerations, make the narrative discourse here into a subject of deep reflections.

The remaining part of this paper will take to discuss how The Wings deconstructs itself by vetoing its own discourse. A method for this is representing the victory of Milly in a way that it necessitates the salvation of Kate as ironical, because the success of the latter entails her failure also, and it can hardly be suggested that she is saved. The dying American girl is now in love with Densher, while she is innocent that he is already engaged to the English beauty. But to have the upper hand in the fight, the beauty fuses an intricate scheme: her lover should marry the American girl so that they (Kate and Densher) can lawfully possess her fortune after her death. Now they are in Venice where Milly is in her deathbed in Palazzo Leporelli. But however the English girl will soon go back to London, for the fulfillment of her design, she wants Densher to stay with the American heiress so that, as he asks Kate, it be "possible she may offer marriage?" (ibid., p. 544) But as he is full of desire, he will stay with Milly in Venice only if Kate comes to his room to sleep with him.

Kate: "And if I do understand?"

Densher: "I'll do everything."

Kate: "Well, I understand."

Densher: "On your behalf?"

Kate: "On my behalf."

Densher: "You'll come?"

Kate: "I'll come" (ibid., p. 546).

In the end however, Kate's ring turns out to be far from heroic, because she has neither Densher for husband, nor the fortune of Milly through Densher; and she feels terribly exhausted, alienated.

Book 9 immerses Densher into a more detached process where musical and theatrical images help him to feel the real fluidity of a "supreme recognition." As he realizes that he should depart for the palace, the experience of his possible marriage to a dying girl to snatch her money is traumatic, and he finds himself steadily swaying to and from Kate: "When he closed the door behind him for an absence he always shut her in" (James, 2004, p. 550). On the one hand, the narrative has it that his salvation should be in his absence from Kate. But his sense of inadequacy in her absence is so overwhelming that he cannot sweep her presence from the realm of his being. Now that Kate is "all in her poor rooms" (ibid), although he feels "the mercy of the beneficent chance," he also admits on reflection that he feels the

\footnotetext{
3. "James's Idea of Structure," PMLA, vol. 80, No. 4, 1965, p. 420.
} 
improvement of a fallacy, for he imagines Kate's scheme is efficient enough to leave "no way" for Milly "but to require it of him" (ibid., p. 553).

Now her deception puts him also on the fringe of lying. And the energies of the narrative go counter so squarely that neither the reader nor the English lover can guess he will be exempted from the inevitable lie. But the story moves forward in a way that it demolishes Kate's dissimulations also. Densher perceives that Kate has restricted his freedom by making him not only to pretend he loves the American girl but also to endeavor to clutch her fortune. Also, these clever policies of Kate inflict some unbearable damages on Milly which he charges to the account of the English girl. Among them is that they have denied the humanity of the American heiress due to which she feels deeply humiliated. And to complete the narrative procedure, these appearances of Kate, that is, her swindles, pretensions, and metaphoric manners cause Densher in due course to take his love back from Kate. Thus, before long she also will feel humiliated, because her lover will desert her.

Milly informs Densher that "If I want to live, I can" (ibid., p. 558). But her life can be comprehended only in the sphere of the metaphorical, in the realm of the appearance. It is definable perhaps only in terms of the spiritual, in terms of "light and sound," for it is through her virtual death that she will reach into the core of freedom. On the verge of death, she is "the freest person" who has "got everything," for it is her "way" to "peace and plenty" (ibid: 560). But how can Milly deal with the Densher whom Kate has adapted for her purposes?

Densher's internal conflict is also a crisis; and he feels snubbed and frightened, because in Kate's project, which he is carrying out, lying is strategic. His remaining 'with' Milly is really 'against' her, but Kate has made him pretend that it is 'for' her. Also, his distance and negligence render the strategy more inapplicable. When Densher sits in Florian's café to refresh himself, we see him in an impossible situation, because his shares are but frailty, fear, indecision, and terror. The images here illustrate his great trauma: the image of someone who must untie a most confused coil, the image of someone who is "shut up to a room" and must witness as long as possible the remaining on the wall of a painting that is hanging most precariously. And the atmosphere of the tale is of non-communication. Also, there are many linguistic and literary signals at work here which suggest a deep stasis: that the air is "a virtual non-conductor" (James, 2004, p. 567), that Pasquale is dormant, that "vacancy is but a nest of darkness" (ibid: 568), or that the force of veto is laid there in the house. To quote Bradbury once again, "what the reader experiences are the leaps of recognition Densher makes, not explanation" (1979, p. 114).

Thus, the discourse of The Wings should be discussed preferably from within rather than from without, which involves, among other elements, a number of syntactic and semantic factors for providing fluidity and relationality. For example, the use in the story of numerous indefinite pronouns like "something", negation expressions like "nothing", possibility words like "might" and "might have", and modal adverbs like "as if" suggests that the free play of the sign in this tale provides a large centrifugal energy which guarantees the fluidity, indeterminacy, and deference of signification. ${ }^{4}$

Such indeterminacies also support the suspicion of a conspiracy in The Wings which seeks to repeal its own discourse. When Densher sees Mark in the Venice café, he remembers several weeks ago when he had seen him in Milly's palace. Now, why he should be in Venice again keeps his mind "restless." Meantime, he continues his self-deceiving considerations more insistently. For example, he thinks Mark's visit to her is a "descent, an invasion, an aggression," and decides that "the only delicate and honorable way of treating" her is to "treat her as he, Merton Densher, did" (James, 2004, p. 577). The contrast of these two strategies of the false is highlighted: One opponent wants to pierce a hole in the game of his rival to repeal its function, while the other one intends to play his game round and round in order that he finds a short cut to his goal. In his renewed entanglement, and as he remains in his place or roams about the square, Densher searches apologies perhaps for the expiation of his shame: slow walking in the rain, "peeping into the shops," and considering what he can get out of a possible meeting with the people around there. Although his stay with the American innocent to grab her fortune (for Kate) goes counter to "the agreeable," Densher says it "would be his one way;" and he will remain "to mark his virtue beyond any mistake" (James, 2004, p. 579).

The talk between Densher and Mrs. Stringham in Venice, which is mainly about if the American girl "should like to see" him, is another façade of the kingdom of deception in The Wings. He will stay with her in fact to excite her to propose marriage, but he pretends he will see her only if she wants "it first herself," and if he can help her. Then they negotiate as to if Sir Luke Strett will come to visit the dying girl. As she is on her deathbed, they might suggest she needs their real help; but they talk only about the luxuries, rather than the fundamentals, of their experiences: what they know about the doctor, for example, or if they like him. Such a piece of talk is functionally metaphorical, because in its irrelevancy to the critical occasion, it befogs the situation for baffling the reader.

\section{Structural Biaxiality}

When Stringham tells Densher she has come to let him know that Mark has returned to Venice to tell Milly "you've been all the while engaged to Miss Croy" (ibid., p. 596), what he needs to understand is perhaps more than this simple fact. His dialogue with the lady is also a remarkable maneuver of metaphorical signification. However, to speak with Kohan again, a function of his measure is that it "apparently brings about a deadly difference for the spectral figure on

\footnotetext{
${ }^{4}$. In this story, "Something" (256 times), "Nothing" (329 times), "Might" (530 times), "Might have" (145 times), and "As if" (292 times) have been used.
} 
the "elegant plane of representation'" (p. 146). From now on, and in the divulgement of the secret of their engagement, Milly will come down from the precipice of the divine to the plain of a dying girl who is a victim of deception and an object of the pity of mortal creatures.

Kohan argues that by this act of metaphoric realization James provides the narrative with a more "general economy" which adds to its plausibility. To achieve enough plausibility, the narrative embeds dimensions of unreality in the real, and represents the former in a way that we presume it as real and believe in it. For example, after Mark's maneuver, Milly is metamorphosed to an "incarnate being." She comes from the remote world of the imagination to the fleshy realm of the real where man can intrigue against man for his own advantage.

Therefore, Jamesian narrative techniques of different kinds make The Wings into a "wonderful system," into a labyrinth to disclose the secret of which often needs lots of know-how and intellectual energy. And his narrative hints are often inclined to escape from the reader. However, the reader of this novel realizes that Densher's present situation (his avoidance, stasis, and fear for example) are the outcomes of such hints. In this way, one realizes that this story simultaneously works in two opposite directions: it works for narrativity, and it also works for ending the movement of the narrative machine.

But the story has not yet consumed all of its productive energy, and is still working. The oblique condition which James creates around the issue of Kate intrigues the reader in a further way. On the one hand, she still believes in the function of "the beautiful system," because although she intends to lawfully possess Milly's fortune after her death, she also wants to help her to be loved by a man before her death. On the other hand, she seems rather unaware of her dishonesty, and prefers not to realize the irony of her system. In such a situation, the free play of the sign in the binary opposition of "innocence/experience" makes the story into a new space of deconstructive analysis. At the end, the novel shows her a poor girl and a monster, because the victimization of the English lover and the American innocent is the outcome of her dishonesty also.

Book 10 begins the presentation of Densher at Lancaster Gate again where he is "gathering everything up, everything he should tell" (James, 2004, p. 622) Kate about his Venice days. She asks him if the American girl is still alive. When he is describing his situation there, the English girl is "divided between the wish and the reluctance to hear it" (ibid: 626). Is her reluctance due to the fact that she guesses Densher may really have fallen in love with Milly? If it is, then we can deconstructively read a narrative only in the nooks and corners of it where its normal movement terminates and the malicious forces its discourse open a new way of narrativity. When Densher reports that the American girl "has turned her face to the wall" because Mark has informed her they have been all the while secretly engaged, she asks him "wouldn't it have been possible then to deny the truth of the information?" (ibid., pp. 630-631). Kate's wonderful suggestion of such a denial of truth stupefies him so much that he wonders if she still believes in their (Milly's and Dasher's) engagement. In this way, Kate also begins to be more heavily influenced by an unreality, a vacancy, a strategy of the false.

The remaining part of the story illustrates how the energies of this possible denial change it to a clear necessity. When Densher understands that for Kate the end justifies the means, and therefore he loses his confidence in her and takes his love back from her, the story comes full circle. He says "I'm just where I was" (James, 2004, p. 656), and thinks that Kate also has no better situation. Her wonderful manner (in negotiation with Densher) to achieve her goal is "the manner of at once having it all before her and yet keeping it all at its distance" (ibid., p. 632). Her manner is a biaxial narrative mechanism which enables her to consume and preserve her resources at the same time. Admitting the complexity of James's narrative technique here, James E. Mulqueen argues that Kate's imagination reaches fulfillment to entangle herself: "what really happens is that Kate, having successfully created the impression that she does not love Densher, is trapped by that appearance, for she convinces Densher himself" (p. 137). Kate's manner also characterizes the Jamesian way of telling the tale: like Kate, he avoids from delivering the tale wholesale, but each time he gives only a portion of it to the reader. This narrative segmentation is another policy in the hand of James for deferring signification. However, Densher's stupefaction in his attempt to act out the scheme of Kate should also be charged on the account of bewildering the reader as a further method for blocking signification. In this way, Milly is perhaps the incarnation of the secret of narrative in James's novel, the incarnation, to rephrase Tzvetan Todorov, of a perpetual search for something which is always absent. ${ }^{5}$ She embodies the value of a continuous enquiry, a search for nothing other than the search itself, a kind of search as the meaning of life. When, back in London again, Kate asks Densher if he has denied Mark's information as to their engagement, he replies that even if he had enough time for the purpose, he would not have denied it, for had he done so, he says, he would have stuck to his denial and would break with Kate to make a truth of his denial. And when Kate infers that he is in love with (the memory of) the American girl, he does not deny it.

In Densher's last visit to Milly, when she insists that he should not stay more than twenty minutes, she wants him to be absent when she dies, and this she does in order for him not to endure the grief of her death. This affects her moral

\footnotetext{
5. For example, in The Poetics of Prose, he describes the works of James in this way: This author grants no importance to the raw event but concentrates all his attention on the relation between the character and the event. Further, the core of a story will often be an absence (the hidden, the dead, the work of art) and its quest will be the only possible presence. Absence is an ideal and intangible goal; the prosaic presence is all we have to work with (p. 184).
} 
measures more than enough. But it is a measure of veiling also, an authorial technique which keeps Milly in the focus of our attention. In addition, it is for preserving her memory, her love, in the hearts of Densher and the reader.

\section{E. A Policy of Concealment}

Milly is severely ill. But as long as she is visible she is reluctant to let the people know she is ill. She shows herself sick only when her death is impending. On the other hand, when she is dying she finds out that Densher has seen his salvation in something other than leaving. Days later, when she understands that he is still there waiting, he says "This ... affected her." Therefore, the outcome of Densher's experiences in Venice is different from what Kate has been dreaming; and she guesses that they are in real love now.

However, these occasions of excessive wonder and reflection have left Densher bereft of all his potentials; for, as Bell Millicent says, the opposing forces of "the naturalistically definable and the transcendentally undefinable young woman are going counter in his inside" (p. 308), and have robbed him of all his abilities for action. He can find no middle action, and whatever he may do is far from truthful. His incapacity is so salient that beyond pondering on "the difference between acting and not acting" (James, 2004, p. 396), he scarcely can do anything.

At the end of this book, the narrative situation becomes even more enigmatic. There is a power game that prevents any ultimate solution to the problem of Kate and Densher. The English lover receives two letters the second of which is from an American law firm. But when he gives it, unopened, to Kate to test her, she fails to pass the test, because he understands from her conduct that money is more important for her than love. Can love and money come together to make them happy? In order to get out of his marriage contract with Kate, Densher gives her the money that Milly has left for him. But Kate also will leave the money on the table. Love and money are intertwined, but Kate and Densher will not marry.

Then, when again he visits her, this time in Mrs. Condrip's, to give her the letter he has received from Milly, and also to find out how Mark knew about their engagement, he thinks Kate (or her Aunt Maud) may have uncovered the secret to Mark (so that he might reveal it to Milly). Kate doesn't "pretend to know" the connection between Mark and her aunt, but she says Mark is "clever enough, apparently" to understand what a riddle hides.

Therefore, Milly's letter, which Densher gives to Kate with an unbroken seal on it, is perhaps an allegory of reading The Wings, for no one can assert to know the real content of it, because shortly after breaking the seal, Kate had "turned to the fire, ..., and, with a quick gesture, had jerked the thing into the flame" (James, 2004, p. 694). She thinks that Densher now owns at least part of Milly's fortune. Therefore, she puts the letter into fire perhaps to make him forget the memory of Milly's love, and thereby to re-possess his heart. The burning letter, at which Densher only stares, is the representation of something for which we search but which we always miss. And can it be suggested that the passive gazer represents the modern reader whose "editorial mind" makes him incapacitated in reading the text of Kate?

Renunciation is still a further way for deferring signification in this novel. Densher's ultimate renunciation of both Kate's love and Milly's money is a due response to his desire to "escape from everything." This can be compared to Lambert Strether's fantastic act of abandonment at the end of The Ambassadors. Maria Gostrey, who has been quite sympathetic to Stretcher, now offers herself to him and suggests he can stay in Europe and live with her. But he rejects all the advantages of life in Europe with her. Soon he will say good-bye to her, and will depart Paris for America. Strether's and Densher's heroic acts of renunciation are Jamesian solutions to achieve spiritual excellence through the rejection of the material gain. They are also among the incarnations of Jamesian strategies to avoid any crisis in reading and interpretation; for through renunciation, the intellectual Densher provides the ground, not for the cancellation of this ugly reality, but for the application of his social consciousness to provide virtual spaces where our private and social experiences can be re-structured.

Densher's renunciation also gives the reader of The Wings the opportunity to apply the free play of his mind to reread it in the context of his new social awareness. This means the freedom of the sign from conventional signification, and the interaction of all discursive forces of the narrative to value dialogic understanding. It is also perhaps James's formula for the imaginative possibility of the impossible. Kate can possess the money only through Densher, and Densher can renounce it through Kate. Such a narrative biaxiality takes function through the free play of the imagination which often looks to the horizons of the impossible.

Thus, another dimension of a deconstructive reading of this novel is the strategy of concealment. James the modernist story-writer is considered having as much insight about (the secret of) his narrative as Milly's doctor has about her problem. Concealment strategy enables James to remain always on the surface of narrativity, and to be inside and outside of it at the same time. As The Wings conceals the nature of sickness of the American girl, it also reveals no resolution for its own internal conflict, and the construction of it entails the destruction of it also.

\section{CONCLUSION}

The later phase of the fiction of Henry James provides a sharply different mode of intelligibility from the traditional ones in the English fiction of the Victorian Times. In this paper we tried to explore a major novel in his later phase to show how he provides such a modernist style of signification. To achieve this purpose, James escapes the Victorian literary vulgarism mainly through taking story in the service of language. In this way, a most outstanding feature of his fiction in this phase is an innovative approach to language, an approach which makes it possible for him to provide the 
possibility of metaphorical signification. Therefore, metaphor in the hand of the later James is the guarantee of the production in language spaces of both false characters and virtual situations as a possibility of new modes of signification which are based on a close interaction of the text and the reader. The Wings of the Dove grounds metaphorical signification in a number of ways. The application of these ways of metaphorical signification makes this novel into a productive domain of deconstructive analysis, because they render it a de-centered verbal structure where experience is not already stored in the word but is the product of the free play of the sign.

Water as symbol in this novel perhaps mainly signifies the fluidity of experience, the fact that as substances of experience, different impressions immediately and spontaneously intrude the consciousness of its characters while they have no control upon them. It also means that experience cannot be the result of detachment of the character from the realities of life, but it is the outcome of life illustrated in a narrative, that is, it is in the context of life represented in narrative that experience is created. Therefore, experience is not only relative but relational also.

Another way in which James provides the ground for metaphorical signification in this novel is creating Milly Theale as different from what she really is or from what we expect her to be. Such an appositive narrativity makes the reader really shocked, because on the one hand he always searches for her, while on the other hand his search is always in vain. However, the vacant position of her in the narrative is a possibility of new experiences through critical interpretation.

A next tool in the hand of James for metaphorical signification in The Wings is the production of ubiquitous shows and appearances. An appearance is something in disguise, something that presents itself not as it really is but as something which it is not. Therefore, the reader of this novel has mainly to deal with illusions, unrealities. The application of illusions for realities in this novel makes experience quite blurred and illusory. Therefore, in the later narrative style of James, experience is not logo-centric but is always marginal and centrifugal also.

In addition, the biaxial construction of this novel makes it something like a self-contradictory mechanism. The free play of the sign simultaneously both structures it and cancels its structuration. Kate Croy plots to possess the fortune of the American heiress after her death. And it is right that she dies when Densher has not yet married her. But her death not only brings the narrative to a termination, but also makes it impossible for her English rival to have both her money and Densher as husband.

The last technique which James uses for metaphorical signification is a policy of concealment. In the later style of James, concealment is the economy of a perpetual searching for something which is always absent. The reader of The Wings perpetually searches for the reality of Milly, but when it changes her to a metaphor, the meaning of his searching is only a searching, because the story nullifies all of his searches. In the metaphoricality of Milly, wherever the reader goes, there is only language out of which the reader cannot go.

\section{REFERENCES}

[1] Bradbury, N. (1979). Henry James: The later novels. Oxford: Clarendon Press.

[2] Bradbury, N. (1985). "'Nothing that is not there and the nothing that is': the celebration of absence in The Wings of the Dove." in Henry James: fiction as history. Ed. Ian F. A. Bell. London: Vision Press Ltd, 82-97.

[3] Bressler, C. E. (1994). Literary criticism: an introduction to theory and practice, New Jersey, Prentice-Hall Inc.

[4] Derrida, J. (1966). "Structure, sign and play in the discourse of the human science." in Writing and difference by Jacques Derrida. Trans. by Alan Bass. London and New York: Routledge Classics , 2001, 351-370.

[5] Derrida, J. (2003). "This strange institution called literature: an interview with Jacques Derrida." in Deconstruction: critical concepts in literary and cultural studies, vol. 2, Ed. Jonathan Culler. London and New York: Rutledge, 3-34.

[6] James, H. (1903). The ambassadors. rep. with an introduction by Harry Levin. London: Penguin Classics, 2003.

[7] James, H. (1904). The golden bowl. Reprinted Edition. with James's preface to the novel and an introduction and notes by Nicola Bradbury. Hertfordshire: Wordsworth Editions Limited, 1995.

[8] James, H. (1902). The wings of the dove, with a preface by Author. New York: The Modern Library. 2004.

[9] Jefferson, D. W. (1964). Henry James and the modern reader. Edinburgh: Oliver \& Boyd.

[10] Leithart, P. J. (2005). /LITERATURE.COM/"Derrida and Metaphor." Posted on Friday, December 23, at 5:30 PM. http://www.leithart.com/2005/12/23/derrida-and-metaphor/ (accessed 25/08/2013).

[11] Matthiessen, F. O. (1944). Henry James: the major phase. London: Oxford UP.

[12] Millicent, B. (1991). Meaning in Henry James. Massachusetts: Harvard UP.

[13] Mulqueen, J. E. (1971). "Perfection of a pattern: The structure of the ambassadors, the wings of the dove, and the golden bowl." in Arizona Quarterly, Vol. 27, No. 2: 133-142.

[14] Norris, C. (1982). Deconstruction: theory and practice. $3^{\text {rd }}$ ed. London: Routledge, 2002.

[15] Short, R. W. (1946). "The sentence structure of Henry James." in American Literature, Vol. 18: 71-88.

[16] Short R. W. (1953). "Henry James's world of images." in PMLA, Vol. 68, No. 5: 943-960.

[17] Todorov, T. (1977). The Poetics of Prose. Ithaca, New York: Cornell UP.

[18] Ward, J. A. (1965). "James's idea of structure." in PMLA, Vol. 80, No. 4: 419-426.

Ali Taghizadeh is an assistant professor at the English Department of Razi University of Kermanshah, Iran, where he has taught English Language and Literature at graduate and undergraduate levels for about 16 years. He has got a B. A. in English from Shiraz University and an M. A. in English from Tehran University. The title of his M. A. thesis is "The Archetypal Theme of Expiation in Six Major Novels of Thomas Hardy and William Faulkner: A Comparative Analysis." He has also got a Ph. D. in "American 
Studies" from John F. Kennedy Institute for North American Studies of Free University of Berlin. The title of his doctoral dissertation is "Structuralism and Its Aftermath in the Fiction of Henry James." "Novel", "Literary Theory", "A Survey of English Literature", and "Literature in Linguistics" are among the courses which he has usually taught. In the coming semester, he will start teaching a doctoral course: "Contemporary English Fiction". The main research interests of Ali Taghizadeh are fiction, literary theory, narrative studies, and literature in language. He has translated J. Hillis Miller's On Literature into Persian, and has published some research articles both in English and in his mother tongue. He is the English editor of Narrative Studies, which is a research journal published by the Department of Persian Language and Literature of Razi University. 